\title{
Race, taxonomies, and proverbs in Latin American and the Caribbean Discourse
}

\author{
Maimouna Sankhé
}

\author{
Senior Lecturer \\ Department of Modern Languages \\ University of Ghana, Legon, Ghana \\ Email:msankhe@ug.edu.gh/msankhe@hotmail.com
}
Submitted: April 14, 2018 / Accepted: February 15, 2019 / Published: October 4, 2019

\begin{abstract}
This paper analyzes how race, taxonomies, and proverbs in Latin American and Caribbean societies are interrelated. These taxonomies and proverbs which first gained currency during the $19^{\text {th }}$ century when the now discredited notion of scientific racism was in vogue, contributed to dehumanizing the others of colonial conquest in the Americas, including the Blacks and Native Americans. This paper, however, mainly focuses on the experiences of the Blacks and demonstrates how the prejudices resulting from colonial era cultural transactions determined and continue to determine the nature of taxonomies and proverbs in Latin America. This paper will situate its findings on the propositions of Édouard Glissant, Fernando Ortiz and José Vasconcelos on race, taxonomies and ethnicity in Latin America and the Caribbean. This paper concludes that such denominations, taxonomies or sayings were created by the hegemonic culture with the sole aim of dominating the populations involved as well as subjugating them to ill-treatment. The study also makes it obvious that there are many expressions that were born within a colonial context and yet have survived over time, and continue to appear in literature and popular parlance.
\end{abstract}

Keywords: Taxonomy, Latin America, race, prejudice, proverb 


\section{Introduction}

The discovery of the Americas by Europeans and the subsequent conquest and colonization of its territories created a new reality that Gaston Baquero defines as indios, blancos y negros en el caldero de América (1991) [Indians, Whites and Blacks in the cauldron of America (1991)]. With the arrival of the new settlers, the ethnic composition and the culture of the continent changed radically. This new heterogeneous and mestizo reality translated often into new forms of prejudice when it came to naming the others. The famous saying "who does not have inga has mandiga" ("if you do not have gringo roots you have African roots"), attributed to the Peruvian politician Ricardo Palma, summarizes the complex mixtures of blood in post-Columbian America.

Thehegemonicculture used different taxonomies, sayings and proverbs to refer to the others, in this case, the Blacks and Indians of the Americas. The chronicles of the Indies produced by various European explorers played a very important role in representing the first visions of the Europeans of the native Americans. The letters of the chroniclers contributed to propagation of the myth of the "noble savage" in which Indians or Native Americans were considered as being savage and kind. The first of these denominations may be the word "Indian" that Christopher Columbus used by mistake to refer to the inhabitants of the lands he had just found or "discovered." Just as the Native Americans or Indian, blacks brought from Africa as slaves were stripped of their original identities and had a new one created for them by the European colonizers. Once in America, these slaves were no longer considered as Africans; they were collectively labeled as 'blacks'.

In the first section of this paper I analyze how these taxonomies dehumanized and stripped the others-in this case the Blacks and also Indians - of their identity although the emphasis of the analysis will be on the Black experience in Latin America and the Caribbean. In the second part I emphasize the relationship between taxonomies of colonial discourse and labels related to the animal world. In the last section I dwell on the connection between proverbs and social imaginaries, and their survivals over time. 


\section{Methodology}

The methodology employed in this paper was to analyze three main studies on race in Latin America and the Caribbean by the Cuban Fernando Ortiz (1906), the Mexican José Vasconcelos (1925), and most recently, the Antillean Édouard Glissant (1997).For Glissant, ideally creolization presupposes that the cultural elements present in the cross-cultural and racial cauldron of America are "of equivalent value" and this is what enables the creolization process to go on in a fair and even manner. According to Glissant, however, this is not what happens in countries where, because of the consequences of slavery, the cultural values of Africans are despised, meaning that the creolization process has been unfair to Blacks. This negative conception about Africans influenced the first investigations of the Cuban ethnologist Fernando Ortiz who analyzed what he considered the anti-social character of the Blacks whom he calls the "Afro-Cuban Hampa or riffraff". Ortiz's Los negros brujos was written in 1906 when the nineteenthcentury ideas of scientific racism were still popular. In fact, the prologue to Ortiz's work was signed by the Italian medical doctor, anthropologist, and criminologist Cesare Lombroso, who believed in the genetic origin of crime.

Relatedly, in his seminal essay, Raza cósmica: misión de la raza iberoamericana (1925), Vasconcelos exposes his thesis on miscegenation in Latin America and the destiny that converts the mixed races of IberoAmerica into "la primerarazasíntesis del globo" (Vasconcelos, 1925, p.29) (the first synthesized race of the globe, own translation). In this synthesis called "fifth race" or "cosmic race", all races will be included without exception. Vasconcelos' racial hierarchy ranged from the "superior ideals of the white" to "the races that could be considered as inferior" (Razacósmica, 1925).The reference to the Ibero-American race as the "cosmic race" in Vasconcelos' title is significant insofar as it reveals the ideological scope of its author's aspiration to create a "cosmic race" whose mission is the ethnic improvement of the Negro and the indigenous peoples. Blacks and Native Americans have a place in this new race if they mix with the "superior race" whose contributions altruistically improve the traits of these two ethnic groups.

I combinethesethreestudies on race because Vasconcelos, in a Mexican context where Blacks were a minority, tried to encourage miscegenation to eliminate Blacks and Native Americans or inferiors in general through ethnic improvement. Similarly, Ortiz, in his first investigations, sought 
to dehumanize Blacks in a country (Cuba), where they were important in number, by calling them "Hampaafrocuba" (Afro-Cuban riffraff).

But Glissant, who is of African descent, provides a more acceptable middle ground in that conversation by arguing that respect for the individual cultures involved in a mestizaje is a condition sine qua non for an effective co-habitation between races and cultures.

I determine how some of these studies dehumanized Blacks in Latin America and the Caribbean and affected them negatively. Such dehumanization and animalization of Blacks is further explained and confirmed by the prejudice employed in Hispanic sayings and proverbs, starting from the advent of European colonialism in the Latin America. I also demonstrate the connection between race, taxonomies and proverbs. When theories on race accept that there are "superior races" and "inferior races", this allows them to dehumanize the so called "inferiors". Then the social imaginaries retain such dehumanization which leads them to create negative taxonomies, sayings and proverbs related to Blacks.

The originality of this paper is in the fact that it analyzes the deep connection between race, taxonomies and proverbs in Latin American and Caribbean discourse. In addition, it refers to how this interrelation between race, taxonomies and proverbs is reflected not only in Latin American fictions but also in the Spanish Golden Age literature. Finally the study shows how these prejudices continue to exist in the Hispanic World.

\section{Taxonomies and identity}

The arrival of Columbus to America is considered as the beginning of the first contact between the Europeans and the indigenous people of America. This occurred in 1492 when the Italian navigator arrived on the coasts of America with the support of the Catholic kings of Spain. However, Columbus did not realize that he was in America because his original purpose was to go to Asia. By mistake he came to America but thought he was in Asia, so the first thing he did was to name the indigenous people he had just met as Indians. That misnomer has survived over time. Columbus opened the way to the colonization and conquest of the lands of these Indians. Like Columbus, many other conquerors and colonizers wrote letters to the Spanish Crown to describe the people and lands they had just discovered. These so-called chroniclers of the Indies had the privilege of describing and naming the others, taking into account political, economic 
Sankhé, M. /Legon Journal of the Humanities Vol. 30.1 (2019)

and religious motives. These Indians were often described as savage, naive, fearful and without religion; easy to conquer and convert to the Catholic religion. For instance, in his letter to Luis de Santángel, an employee at the Spanish Royal Crown at that time, Columbus said:

Andan todos desnudos, hombres y mujeres [...]. Ellos no tienen hierro ni acero ni armas [...]. Son muy temerosos [...]. Y no conocían ninguna secta ni idolatría, salvo que todos creen que las fuerzas y el bien es en el cielo, y creían muy firme que yo con estos navíos y gente venía del cielo y en tal acatamiento me recibían en todo cabo después de haber perdido el miedo (Serna 2007, pp. 119, 120, 121).

[they walked about naked, both men and women [...]. They have neither steel nor weapons [...]. They are very shy and timid [...]. And they do not belong to any sect or practice idolatry, but all of them believe that everything that is good comes from heaven, believing strongly that, my good self and those ships and people came from the sky and for that reason they received me warmly after overcoming their fear (Serna 2007, pp. 119, 120, 121, own translation)].

This impression and others like it contributed to the myth of the good savage or noble savage that would be the counterpoint of so-called civilized European societies. The main motivation was to colonize and exploit the people and lands they had just discovered. This signified the first loss of the identity of these indigenous people which was followed by the disrespect of their culture on the part of the colonizer; a colonizer who, based on his supposed superiority, set out to carry out a civilizing mission. Before being forced under the Euro-generated umbrella category of Indianness, these natives were Mayas, Aztecs, Incas, etc. Colombus and others like him changed the names of their lands and imposed new names on them.

To emphasize an African dimension to the process described above, Elvira Diaz Benitez affirms:

Parto de la noción de que así como se construye cultura, también se construye raza. De hecho la categoría negro corresponde de por sí a un constructo histórico cuya lógica fue de deshumanización y explotación. La raza nació en el Atlántico si tenemos en cuenta que en África no había negros sino africanos; Yolofes, Balantes, Sereres, Biáfaras, Kongos, Angolas, Branes, Zapes, Akanes, Lucumís, Fantis, Ashantis, Ewe-Fon, Ibos y demás pueblos que en la trata se convirtieron en una sola: negros (Díaz Benítez, 2004, p. 124).

[my idea is based on the notion that just as culture is built, so is race. In fact, the black category corresponds in itself to a historical construct whose logic was one of dehumanization and exploitation. Race was born in the Atlantic 
Sankhé, M. /Race, taxonomies, and proverbs in Latin American and the Caribbean Discourse

if we consider that in Africa there were no blacks but Africans:Yolofes, Balantes, Sereres, Biáfaras, Kongos, Angolas, Branes, Zapes, Akanes, Lucumís, Fantis, Ashantis, Ewe-Fon, Ibos; and the other peoples that in the slave trade became one: blacks ") (Diaz Benitez,2004, p. 124, own translation)] .

Similarly, in his article «et la traite créa le nègre: nombrar es crearmonstruos (naming is to create monsters)», Lavou Zoungbo states:

Nommer, dans le cas de l'histoire coloniale et esclavagiste c'est déposséder, prendre possession, biffer une généalogie-histoire, c'est affirmer une toute puissance ou une supériorité. Il s'agit en fait du pouvoir de dire, «tu es noir», «tu es Indien» et «tu le restera». De surcroit, tu reprendras à ton compte et tu répondras aux interpellations liées à ces qualifications, à ces fables, à ces noms (Lavou Zoungbo, 2004, p. 70).

[Naming, within the framework of colonialism and slavery is to strip, take possession of, erase a genealogy-history, is to affirm an entire power or superiority. That is to say, "you are black", "you are Indian" and " you will forever remain so." In addition, you will intend or begin to call yourself black and respond to the questions related to these qualifications, fables, names (Lavou Zoungbo, 2004, p. 70, own translation)].

This erasure of peculiar pre-colonial ethnic identities is what happened in the Americas with the Indians and the Blacks. All these processes contributed to the loss of the aforementioned colonized peoples' peculiar identities and reduced them to European formulated concepts such as Indians or Blacks; because before becoming Blacks or Indians they were Yolofes, Biáfaras, Akanes, Lucumís, Ewe-Fon, Aztecas, Mayas, Incas, etc.

\section{Slavery, taxonomies and the animal world}

This paper demonstrates, in this part, how the context of slavery determined the taxonomies and denominations given to Blacks in Latin America and the Caribbean. For this reason, I base the study on theories that had big repercussions on discourses on race relations in Latin America such as those of the British Francis Galton. In fact, in his essay, La raza cómica: misión de la raza iberoamericana (1925), the Mexican philosopher José Vasconcelos takes up the term "eugenics" coined by Francis Galton, cousin of the scientist Charles Darwin. This concept, according to Peter Wade (2000, p.19): "was based on a scientific racism and on the idea that the reproductive capacities of biologically" inadequate "individuals (for example, the insane) and, more generally, of the "inferior races", had to be limited ". Darwin also has the same conception as Galton on the need to 
Sankhé, M. /Legon Journal of the Humanities Vol. 30.1 (2019)

make disappear the "weak" and the "inferior races", among which were the blacks.

Galton was convinced that the physical, intellectual, moral and even social attributes characteristic of "races" were determined by their different biological nature, and that they were transmissible hereditarily. That is why Galton and Darwin's theses on natural selection and eugenics aimed to eliminate all the inferiorities that opposed the march of progress. Galton went on to say the following: "aunque la mayoría de las razas bárbaras desaparecieron, algunas, como la negra, no" (Soutullo, 1997, p.30) (although most of the barbarian races disappeared, some, like the black, did not, own translation).

In Latin America, taxonomy, race and stereotypes are closely linked with slavery playing a role as important as it is negative in the choice of taxonomies. Afro-descendants in Latin America are confronted with what Michel Certeau once called "Malheur généalogique" ("Genealogical misfortune"/"ill-fated genealogy"). Lavou Zoungbo takes up the issue in "Du migrant nu" au citoyen différé Présence-histoire "des noirs en Amérique Latine: Discours et Représentations (2003): "cuando no existe una liga entre genealogía y privilegios se puede hablar entonces de "desdicha genealógica" [...]. Un ejemplo de esta desdicha lo constituye la experiencia histórica de los afrodescendientes en las Américas" (Lavou Zoungbo, 2003, pp.10-11).

["when there is no link between genealogy and privileges, one refers to "genealogical misfortune" [...]. An example of this misfortune is the historical experience of people of African descent in the Americas" ( Lavou Zoungbo, 2003, pp.10-11, own translation)].

Lavou Zoungbo states that according to the social imaginaries in Latin America, slavery have transformed black people and had left them a "genealogical misfortune".

This "Genealogical misfortune"/ "ill-fated genealogy" as it is called reveals the indelible marks that slavery has left on the lives of the slaves and their descendants. As a matter of fact, Modesto Chavez Franco, as quoted by Paulo de Carvalho-Neto in Estudios afros: Brasil, Paraguay, Uruguay, Ecuador(1971), described the startling difference he (Modesto Chavez Franco) perceived between the pre-Columbian Blacks and those arrived in Latin America as slaves:

Pues es de advertir que en ciertos grupos de negros hay tipos de verdadera belleza, ya varonil, ya femenina. Negras de la región de Limones y otros 
Sankhé, M. /Race, taxonomies, and proverbs in Latin American and the Caribbean Discourse

puntos hemos conocido que, de figurárselas blancas, serían bellísimas en esta raza. De narices perfiladas, finas, prominentes, bocas pequeñitas, labios delgados y rojos; orejas de elegantísimas curvas, cuellos y senos venusianos, cuerpos esbeltísimos con elegancia de aristocracia; altas, gentiles, naturalmente garbosas de aire señoril, fina epidermis y carnes duras; pies pequeños y muy bien torneados, manos largas y finas, dientes de blancura fulgurante y alineamiento y proporción perfectos, ojos hermosísimos de grandes pestañas curvas, cejas finas de bonitos arcos y hasta cabellos sedosos, dúctil y más largo y bien peinable que el abigarrado y duro del negro común [...]. Son, además, aseadas hasta la pulcritud, tanto en su persona como en los vestidos [...]. Vale tener en cuenta que negros había en América desde siglos antes de su llamado descubrimiento [...]. Bien, pudieran pues, estos negros proceder de aquellos grupos prehistóricos, directamente, y diferenciarse por esto tan ostensiblemente de sus similares africanos importados por la colonización. (De CarvalhoNeto, 1971, p.279).

[it is interesting to note that existing among certain groups of Blacks are those (both males and females) endowed with truly beautiful features. If we imagine that the Blacks women we saw in the Limones region and other places were white women, then they would be really beautiful. With beautiful and prominent aquiline noses, very tiny mouths, thin and pink lips; exquisitely-curved ears, necks and breasts like those of the goddess Venus, very slender bodies, tall, graceful, gorgeous and majestic, smooth skin with firm proportions; dainty and well-shaped feet, long and thin hands, perfectly arranged and well-proportioned sparkling white teeth, truly beautiful eyes with long curved lashes, well-curved eyebrows and silky smooth hair that is flexible, longer and more manageable than the uneven and kinky air of Blacks in general [...]. Besides, they are very clean and well- groomed [...].It is worth mentioning that they were Blacks in America for centuries before its so-called discovery [...]. It may well be that those Blacks were the direct descendants of those prehistoric groups but may be so different from their fellow Africans arriving as slaves. (De CarvalhoNeto, 1971, p.279, own translation)].

As a professional criminologist, Fernando Ortiz, in his first investigations, talked about the antisocial aspect of the religious practices of Blacks. At first, he pejoratively called them "The Afro-Cuban Hampa" or riffraff. Ortiz's ideas had been influenced by the theories of the school of Cesare Lombroso who wrote the preface to Los negros brujos, a very important book that signaled the beginning of African studies in Cuba.

Ortiz might have been influenced also by the Brazilian ethnologist Raimundo Nina Rodrigues (1862-1906), whose great love for the scientific theories of his time, led him to defend the degeneration of miscegenation and the inequality of the races. However, over the years, the Cuban distanced 
Sankhé, M. /Legon Journal of the Humanities Vol. 30.1 (2019)

himself from this posture, adopting a completely different one.

Los negros brujos (1906) is loaded with all the prejudices prevalent at the beginning of the 2oth century against the Blacks and their culture. Based on theories about the so-called "superior races" and "inferior races" and those predestined to barbarism or crime, Los negros brujos (1906) investigates what it considers the nature of the African culture.In Los negros brujos, Ortiz states: "la raza negra llegó a través de la esclavitud sin patria, sin familia, sin sociedad suya, con su impulsividad brutal comprimida frente a una raza de superior civilización y enemiga que la sometió a un trabajo rudo y constante" (Ortiz, 1973, p.13).

["the black race arrived through slavery- a people without a homeland, family, neither were they an organized group. With sheer impulsiveness, they came up against a race of superior civilization and enemy that subjected them to hard and constant work" (Ortiz, 1973, p.13, own translation)].

Jose Vasconcelos (1882-1959) proposed "the cosmic race" or "fifth race" in which the said "inferior races" would be redeemed and, after a time, would be absorbed by the "superior races". In the words of the Mexican Vasconcelos:

Los tipos bajos de la especie serán absorbidos por el tipo superior. De esta suerte podría redimirse, por ejemplo, el negro, y poco a poco, por extinción voluntaria, las estirpes más feas irán cediendo el paso a las más hermosas. Las razas inferiores, al educarse, se harían menos prolíficas, y los mejores especímenes irán ascendiendo en una escala de mejoramiento étnico (Vasconcelos, 1925, p.40).

[the inferior species will be absorbed by the superior ones. In this way, Black people could be redeemed, and little by little, by voluntary extinction, the uglier species will give way to the more beautiful ones. The inferior races, when educated, would become less prolific, and the best specimens will go up on a scale of ethnic improvement (Vasconcelos, 1925, p.40, own translation)].

Everything seems to indicate that the sole objective of the creation of this perfect "fifth race" is only to eliminate in a peaceful and "altruistic" way, "inferior races" because Vasconcelos himself is convinced that this is the best way to reach "ethnic improvement".

This confirms the fact that slavery and colonization have contributed to the stigmatization of Blacks. For that reason, Frantz Fanon affirms in his book Piel negra, máscaras blancas that "la desgracia del hombre de color es el haber sido esclavizado" (Fanon, 2009, p.189). 
Sankhé, M. /Race, taxonomies, and proverbs in Latin American and the Caribbean Discourse

["the misfortune of the Black person is to be enslaved" (Fanon, 2009, p.189, own translation)].

These prejudices have been transferred to Latin American literature where the black characters are presented and seen as inferior. In the work of Adalberto Ortiz titled Juyungo, historia de un negro, un aisla y otros negros, it is very common to notice these prejudices in the Black characters of the novel.

The word "juyungo" itself is derogatory because it could refer to any of a monkey, a dirty person, or a smelly person. This is the name the Indians gave their Black neighbors, a name which the main character of the novel, Ascensión Lastre, bears.

Once a race is created, one looks for a name or names that respond to the idea or concept one has of that race; all of which is for the purpose of exploiting and subjugating others to inhuman treatment. If we take into consideration the terms mestizo and mulatto, the former describes the son or daughter of an Indian and white person while mulatto refers to the son or daughter of a Black and white person and vice versa. However, in the opinion of Jean-Luc Bonniol, as cited by Lavou Zoungbo, the word mestizo derives from the Latin mixticum and refers to mixtures of blood especially between animals. It is during the modern age when the term was used to define a new category of people born of mixed blood during the colonial epoch. Likewise, the word mulatto came into existence at the beginning of the sixteenth century and was used to describe the crosses between animals in general and especially among sheep. Then, later the word referred to the children born out of the union between whites and blacks. It is noteworthy that both mestizo and mulatto are based on connotations clearly related to the animal world.

For Lavou Zoungbo (2003), this clarifies a type of taxonomy which racializes the colony in Latin America, such as "Coyote" (In colonial America, born of parents of different races, especially barcino and mulatto, or mulatto and barcino. Barcino refers to the animal world especially that of dogs, bulls and cows), "Lobo" wolf), "Mulatto" (derives from "Mula" (Mule), "Matungo" (horse that is not healthy)", "Bozal" (newly-arrived slave), among others. Even the word "Cimarrón", so highly symbolic during the resistance of the Blacks against their dehumanization, originally meant a wild animal. These are the definitions that the dictionary of the Real Academia Española collects from the word "Cimarron": "indolent sailor and little worker", "domestic animal that flees to the field and becomes mount", "wild animal, not domesticated", 
Sankhé, M. /Legon Journal of the Humanities Vol. 30.1 (2019)

"a plant which can grow by itself in the forest or be cultivated", and also "the slave who took refuge in the mountains seeking freedom”.

Racializing taxonomy was often connected to the animal world. According to the authoritative dictionary RAE, the word zambo, which describes the son of a Negro and an Indian, or vice versa refers to:

Mono americano de unos $60 \mathrm{~cm}$ de longitud, que tiene la cola prensil y casi tan larga como el cuerpo, el pelaje de color pardo amarillento, como el cabello de los mestizos zambos, el hocico negro y una mancha blanca en la frente, rudimentales los pulgares de las manos, muy aplastadas y abiertas las narices, y fuertes y acanaladas las uñas (Dictionary RAE, Twentieth second edition,).

[american monkey which is about six decimeters long with a prehensile tail almost as long as the body. It has the yellowish-brown coat, like the zambo's hair, a black snout and a white spot on the forehead, rough thumbs of the hands, very flattened and open noses, and strong and grooved nails, Dictionary RAE Twentieth second edition, own translation)].

The other words like wolf, muzzle, mulatto, and coyote all come from the animal register.

In her article titled "Alonso de Sandoval y la construcción de las "naciones africanas" del Nuevo Mundo" published in Mots pour Nègres maux de noir (e) s enjeux socio-symboliques de la nomination des Noir (e) $s$ en Amérique Latine (2004), Carmen Bernand states:

La proliferación de los híbridos - castas - con las connotaciones simbólicas y normativas que conllevan (ilegitimidad, deslealtad, vicio, lujuria, metáforas animales) se refleja en un vocabulario que alude a una pigmentación indeterminada, ni negra ni blanca, sino "abigarrada", es decir "de varios colores mal combinados", lo heterogéneo, lo que es sin concierto” (Bernand, 2004, p.56).

[the proliferation of hybrids - castes - with the symbolic and normative connotations that involve (illegitimacy, disloyalty, vice, lust, animal metaphors) is reflected in a vocabulary that refers to an indeterminate pigmentation, neither black nor white, but "variegated", that is to say, "Mixed colors", heterogeneous, which is without concert"(Bernand, 2004, p.56, own translation)].

In conclusion, it is clear that slavery created stereotypes and contributed to the dehumanization of Blacks in Latin America.

\section{Proverbs and social imaginaries}

This dehumanization rooted in social imaginaries is noted in the proverbs and sayings in forms of linguistic prejudices. For example there 
are sayings like trabajar como un negro (working as a black man, own translation), well known in the Hispanic world and that means working more than normal. In fact, some Afro-descendant organizations are fighting to expunge this saying from the dictionary RAE. In Puerto Rico there is the proverb Dios hizo al negro para que el animal descanse (God created the black man in order to grant animals a rest. own translation). Expressions such as es negro pero guapo, es negro pero bueno, es negro pero inteligente (he is black but handsome, he is black but good or he is black but smart, own translation), are also very common in the Hispanic world. The expression merienda de negros (blacks having a snack) which according to the RAE dictionary means disorder, confusion in which no one understands anything, is an expression which came into existence during the period of slavery when Blacks organized small get-togethers after the long and hard day's work, something that the colonial masters considered as rowdy or rollicking good time. It also has the same meaning the expression boda de negros (wedding between Blacks, own translation) which according to the RAE dictionary means, a meeting in which there is much confusion and racket. Quevedo's poem titled Boda de negros (wedding between Blacks, own translation) reveals Europeans' conceptions about the Blacks at the time. However for María Luisa Peña Tristán:

Esta anómala visión del hombre negro no era exclusiva de Quevedo ni fruto de una invención literaria, sino la que, desde muy atrás, se había extendido por toda la península y que los pensadores, teólogos, humanistas... etc. se empeñaron en mantener viva a lo largo de los siglos XVI y XVII. Aunque en Quevedo se plasme de manera más brutal y despectiva esta concepción del negro africano era de todos conocida y peor aún, compartida. Para la mayoría, los negros no eran completamente humanos sino seres tan extraordinarios, salvajes e inusitados como las tierras de donde provienen (Peña Tristan, Thesis, Universidad Complutense Madrid, 2012).

[this anomalous vision of the black man was not exclusive to Quevedo nor was it the result of a literary invention, but one that from a very remote time had spread all over the peninsula and that thinkers, theologians, humanists ... etc. insisted on keeping alive throughout the sixteenth and seventeenth centuries. Although in Quevedo it is reflected in a more brutal and contemptuous way, this conception of the African Negro was known and worse of all accepted. For most people, Blacks were not completely human, but beings that are as bizarre, savage and abnormal as the lands from which they came (Peña Tristan, Thesis, Universidad Complutense Madrid, 2012, own translation)]. 
Sankhé, M. /Legon Journal of the Humanities Vol. 30.1 (2019)

In Latin American literature on Blacks, the concept of race is repeated very often: hay que mejorar la raza (the race must be improved, own translation) or hay que mejorar el color (the complexion must be toned or improved, own translation), something which was one of the main goals of the Latin American elites of the time who used miscegenation to improve the race. Juan Pablo Sojo's novel Nochebuena negra addresses this theme. One of the young Blacks in the novel no longer wants to have a black girlfriend after traveling to Caracas, the capital of Venezuela. He has changed and no longer wants to have a black woman; in Caracas he fell in love with a young woman named Ana Rafaela because, as the young man said to his friend "usté comprende, el colorcito... Hay que mejorarlo, vale. Yo la he corrío en Caracas, y sé lo que es una buena hembra. Además hoy soy otro; me he civilizado; antes usaba alpargatas barbonas, liencillo y andaba jediondo" (Sojo, 1972, p.276).

["you understand ... You have to tone the skin. I have been to Caracas, and I know how good a woman should look. Besides, I am a different person today; I am enlightened; before I wore espadrilles, clothes made of rough material and never smelt good" (Sojo, 1972, p. 276, own translation)].

In another novel on the Black person/on the black reality in Latin America known as Juyungo, historia de un negro, una isla y otros negros by the Ecuadorian Adalberto Ortiz, the customs of the Blacks are considered as barbaric, and Mr. Valdés, one of the members in political circles, had this to say:

Es una verdadera salvajada la de estos negros. La civilización no puede entrar en nuestra provincia con semejantes cosas. Mi labor en el Congreso ha de tender al progreso de este pueblo, de cualquier manera. Necesitamos que venga gente de afuera a mejorar la raza y las costumbres" (Ortiz, 1976, pp.245-246).

[African customs are really barbaric. Civilization is not possible in our province because of such things. My duty in Congress is to promote the progress of the Ecuadorian people, by all means. We need people from outside to improve the race and customs (Ortiz, 1976, pp. 245-246, own translation)].

In Diáz Sánchez's Cumboto, one of the characters affirms:

Mi padre estaba persuadido de que hay que emanciparse de este horrible pigmento que pesa sobre la vida de los hombres mucho más que un delito (...) Su padre (...) había querido casarse con una blanca por mejorar la raza" (Díaz Sánchez, 1973, p.156-157).

["my father was convinced that one must be liberated from this horrible 
Sankhé, M. /Race, taxonomies, and proverbs in Latin American and the Caribbean Discourse

complexion that weighs on the lives of men much more than a crime (...).

His father (...) wanted to marry a white woman to improve the race" (Díaz

Sánchez, 1973, p.156-157, own translation).

It is even very common in Spain to say es una gangá, es una verdadera gangá (this is a good deal or it is a real bargain, own translation).According to the Dictionary RAE, twentieth second edition ganga means something acquired at a price far below what was to be expected. Gangá is a word that derives from slavery and is used to refer to several groups of slaves from Africa who suffered from poor health; this is why they were cheaper than other slaves.According to Rafael Pereachalá Alumá, "los Gangás estaban muy mal reputados, pues su fortaleza física era precaria, de ahí que vendían dos en el precio de uno, surgiendo allí la palabra ganga" (Pereachalá Alumá, 2004, p. 150).

["the Gangás are of very low value, because of their poor health, resulting in a situation whereby two gangas are sold at the price of one, this is how the word ganga came into existence" (Pereachalá Alumá, 2004, p. 150, own translation)].

\section{Conclusion}

In short, I would say that in Latin American discourses, the concepts of race, taxonomies, and sayings are interrelated. In the case of Blacks their status as slaves determined the negative and stereotyped aspect of racializing taxonomies and the sayings that refer to them. These negative attitudes to race and race mixing, as this paper has shown, go back to the days of scientific racism and were mainstreamed by scholars such as Ortiz and Vasconcelos. However, many relatively more positive expressions are used today to tone down the expressions that were used earlier. Moreno is one of such expressions used instead of negro, also gente de color instead of negro. Statements like I am black and not brown or Black is beautiful are now increasingly common in the Americas as affirmations of Black race pride and also as ways of assuaging the harm done by these earlier negative terms. It may appear that the ultimate goal, for most progressive scholars, is to create a space where racial discourses equally respect all groups in contexts of racial and cultural creolization.

Édouard Glissant explains what happened in Latin America and the Caribbean as creolization "une rencontre d'éléments culturels venus d'horizons absolument divers et qui réellement se créolisent, qui réellement s'imbrique et se confondent l'un dans l'autre pour donner quelque chose 
Sankhé, M. /Legon Journal of the Humanities Vol. 30.1 (2019)

d'absolument imprévisible, d'absolument nouveau et qui est la réalité créole" (Glissant, 1996, p.15).

["the coincidence of cultural elements from absolutely different settings which get really creolized, overlap and get confused with themselves in order to create something that is absolutely unpredictable, absolutely new, something that is none other than Creole reality"(Glissant, 1996, p.15, own translation)].

However, in order for creolization to be effective, there should be no "dégradation ou diminution de l'être, soit de l'intérieur, soit de l' extérieur, dans ce contact et dans ce mélange" (Glissant, 1996, p.18).

["no degradation or diminution of the human being, whether internally or externally, in that contact and in that mixture"(Glissant, 1996, p. 18, own translation)]. 


\section{References}

Baquero, G. (1991). Indios, blancos y negros en el caldero de América. Madrid, Spain: Ediciones de Cultura Hispánica.

Bernand, C. (2004). Alonso de Sandoval y la construcción de las "naciones africanas" del Nuevo Mundo in Lavou Zoungbo, V \& Viveros, M. (Eds.), Mots pour Nègres maux de noir(e)s : enjeux socio-symboliques de la nomination des Noir(e)s en Amérique Latine (pp.37-59) Perpignan, France: Marges, Presses Universitaires de Perpignan.

Carvalho-Neto, P. De (1971).Estudios afros: Brasil, Paraguay, Uruguay, Ecuador. Caracas, Venezuela: Instituto de Antropología e Historia, Facultad de Humanidades y Educación, Universidad Central de Venezuela.

Díaz Benítez, E. (2004). La invención de la cultura: el caso afro-colombiano in Lavou Zoungbo, V \& Viveros, M. (Eds.), Mots pour Nègres maux de noir(e)s : enjeux socio-symboliques de la nomination des Noir(e)s en Amérique Latine (pp.119-143) Perpignan, France: Marges, Presses Universitaires de Perpignan.

Díaz Sánchez, R. (1973). Cumboto: cuento de siete leguas. Barcelona, Spain: PLAZA \& JANES, S. A.

DRAE (Diccionario de la Real Academia Española, Twentieth second edition). (www.rae.es)

Fanon, F. (2009).Piel negra, máscaras blancas (1st ed. 1952).Madrid, Spain: Akal.

Glissant, É. (1996). Introduction à une poètique du divers. Paris, France: Gallimard.

Glissant, Édouard. (2002). Introducción a una poética de lo diverso. París, France: Gallimard.

Lavou Zoungbo, V. (2004). Et la traite créa le nègre: "nombrar es crear monstruos"in Lavou Zoungbo, V \& Viveros, M. (Eds.), Mots pour Nègres maux de noir(e)s : enjeux socio-symboliques de la nomination des Noir(e)s en Amérique Latine (pp. 61-77) Perpignan, France: Marges, Presses Universitaires de Perpignan.

Lavou Zoungbo, V. (2003). Du "migrantnu" au citoyen différé "Présencehistoire" des noirs en Amérique Latine, Discours et représentations. Perpignan, France: Collection Études, Presses Universitaires de Perpignan. 
Sankhé, M. /Legon Journal of the Humanities Vol. 30.1 (2019)

Lavou Zoungbo, V \& Viveros, M. (Eds.). (2004). Mots pour Nègres maux de noir(e)s : enjeux socio-symboliques de la nomination des Noir(e)s en Amérique Latine. Perpignan, France: Marges, Presses Universitaires de Perpignan.

Ortiz, A. (1976). Juyungo, historia de un negro, una isla y otros negros (2nd ed.). Barcelona, Spain: Seix Barral.

Ortiz, F. (1973).Los negros brujos (1st ed. 1906). Miami, USA: Universal.

Peña Tristán, M. L. (2012). La esclavitud en la literatura española de los Siglos de Oro. (Doctoral Thesis). Universidad Complutense, Madrid, Spain. Retrieved from http://eprints.ucm.es/15280/1/T33766.pdf

Pereachalá Alumá, R. (2004). La cuestión del autoénonimo in Lavou Zoungbo, V \& Viveros, M. (Eds.), Mots pour Nègres maux de noir(e) $s$ : enjeux socio-symboliques de la nomination des Noir(e)s en Amérique Latine (pp. 145-157) Perpignan, France: Marges, Presses Universitaires de Perpignan.

Sankhé, M. (2016). Presencia del negro en la novela vanguardista hispanoamericana: tiempo y contratiempo. Madrid, Spain: Editorial Pliegos.

Serna, M. (Ed). (2007).Crónicas de Indias. Madrid, Spain: Cátedra.

Sojo, J.P. (1972). Nochebuena negra. (2nd ed.), Caracas, Venezuela: Monte Ávila Editores.

Soutullo, D. (1997). La eugenesia desde Galton hasta hoy. Madrid, Spain: Talasa.

Vasconcelos, J. (1983). La raza cósmica: misión de la raza iberoamericana (1st ed. 1925). México City, México: Asociación Nacional de Libreros.

Wade, P. (2000). Raza y etnicidad en Latinoamérica ( $1^{\mathrm{a}}$ ed. 1997). Quito, Ecuador: AbyaYala. 